\title{
Barriers and Suggested Facilitators to the Implementation of Best Practice: An Integrative Review
}

\author{
Suhair H. Al Ghabeesh \\ Faculty of Nursing, Al-Zaytoonah University, Amman, Jordan \\ Email: suhair alghabeesh@yahoo.com
}

Received 9 January 2015; accepted 25 January 2015; published 29 January 2015

Copyright (C) 2015 by author and Scientific Research Publishing Inc.

This work is licensed under the Creative Commons Attribution International License (CC BY).

http://creativecommons.org/licenses/by/4.0/

(c) (i) Open Access

\begin{abstract}
It is well known that the incorporation of research findings into practice leads to less costs of health care, more personal productivity, longer and healthier lives for patients, and also will decrease pain and suffering of patients. Thus, the aim of this integrative review was to identify the barriers and facilitators of research utilization among the world and the best strategies used to overcome the barriers. A literature search was conducted by viewing relevant studies via computerized searching through EBSCO, Medline, Science Direct, Pub Med, Ovid, and Arabic Journals research databases. The number of reviewed studies was 192 and all of them in English, no studies in Arabic. Only 26 of them were selected based on inclusion criteria. Twenty six studies were included, with most using a cross-sectional survey design. The most identified barriers are lack of time, inadequate facilities and resources to implement new ideas, no enough authority to implement new ideas, lack of administrative support and others, while the most identified suggested that facilitators are improving the scientific knowledge of nurses and support from unit managers. The majority of these studies used Barriers scale which is not a standardized tool. However, there is a big gap between real situation and the identified evidences resulted from researches.
\end{abstract}

\section{Keywords}

Research Utilization, Barriers, Facilitators, Nurses

\section{Introduction}

The "know-do gap" is a very important issue, many institutions work hard to bridge this gap. One of these institutes is "The World Health Report on Knowledge for Better Health" that encourages the investment in research on health system and to set knowledge translation as a priority. As a result to the United Nations Millennium 
Declaration about the importance of bridging the "know-do gap”, the Ministerial Summit on Health Research in collaboration with the Global Forum for Health Research was conducted in 2005. The summit involved more than 900 participants from 109 countries. Multiple important messages about how to achieve the Millennium Development Goals (MDGs) and the importance of real application of existing knowledge into practice were included [1].

Additionally, in Geneva in the year 2005, many experts in research met to discuss the concept of knowledge translation and how they can set priorities of global health and strategies for knowledge translation and action [1].

The Jordanian Nursing Council (JNC) responded to this recommendation by putting the support to scientific research as the most important priority [2]. However, nurses in clinical areas face many barriers to implement research findings [3]-[8]. These barriers differ from country to another and from clinical area to another. According to World Health Report on Knowledge for Better Health [1], the presence of these barriers especially in developing countries will affect the achievement of the MDGs that must be achieved by 2015 mainly due to the lack of human, financial, and informational resources. Santesso and Tugwell stated that less than $10 \%$ of health research money is spent on diseases affecting developing countries [1]. Thus, this integrative review focused on barriers to RU and explored the facilitators to RU and the strategies used to increase RU.

\section{Search Method}

Research papers published between 1998 and 2014 were identified via searches from the following databases: EBSCO, Medline, Science Direct, Pub Med, Ovid, and Arabic Journals research databases. Searching was conducted using the following keywords: "Barriers to research utilization (RU)", "Facilitators to RU", "RU" and, "registered nurses". Inclusion criteria: a study was eligible for inclusion if the study written in English and in Arabic, identify the barriers and facilitators of RU among nurses and used the words "research utilization" not "evidence based practice". Exclusion criteria: a study was not eligible for inclusion if the study written in another languages, review papers, evidence reports, comparative studies, studies conducted in educational areas and the sample not nurses or other health professions with nurses.

\subsection{Search Outcome}

The search produced 192 studies, all of them written in English, no studies written in Arabic. All of 192 were assessed against the inclusion criteria. The researcher initially selected the papers by reading abstracts, in some cases; the full paper was required to determine if the study met the inclusion criteria. One hundred and sixty six studies, which failed to meet the criteria, were excluded, leaving 26 research studies summarized in Table 1.

\subsection{Data Abstraction}

From the 26 selected studies, the following data were abstracted and inserted into Table 1: author(s) and year of publication, purpose of the study, theoretical framework, country, sample size, design and finally the main findings. The process of selecting the final 26 studies is outlined in Figure 1.

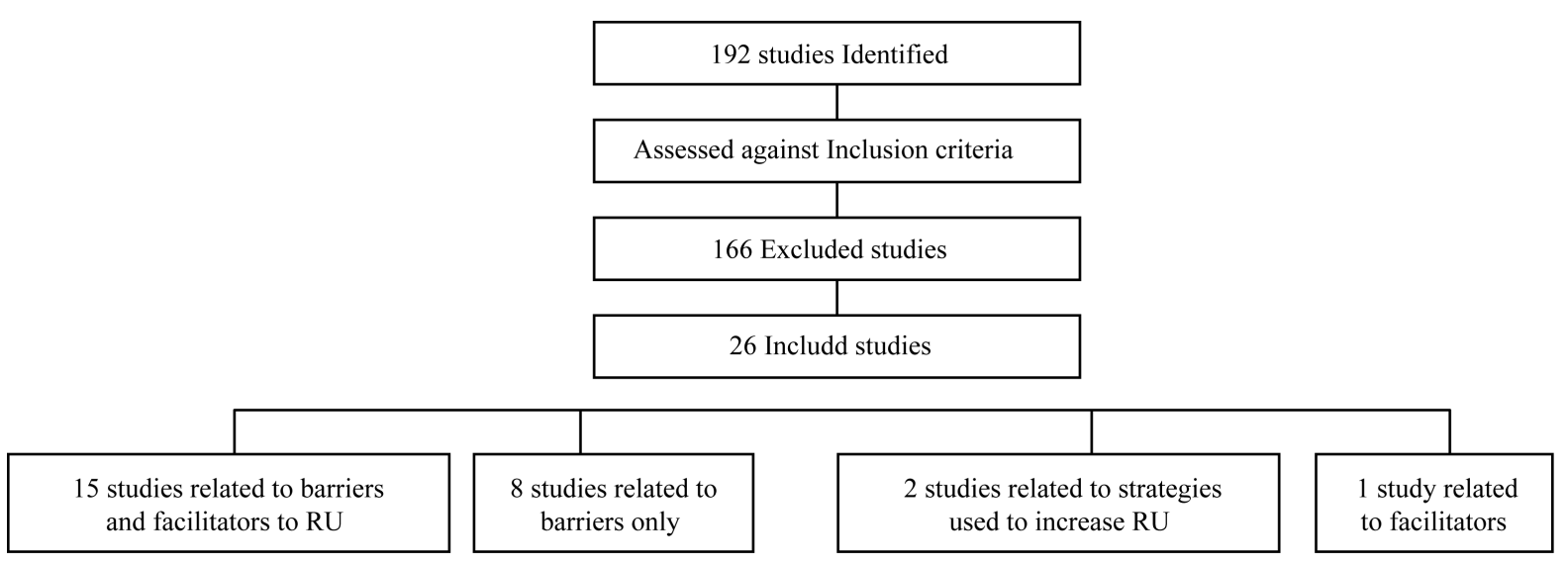

Figure 1. The process of selecting studies. 
Table 1. Chronological list of the studies that identified barriers and facilitators of research utilization.

\begin{tabular}{|c|c|c|c|c|c|c|c|}
\hline No & Citation & Purpose & $\begin{array}{l}\text { Theoretical } \\
\text { framework }\end{array}$ & Country & $\begin{array}{l}\text { Sample } \\
\text { size }\end{array}$ & Design & Main findings \\
\hline \multicolumn{8}{|c|}{ Reviewed studies in the field of Barriers to research utilization } \\
\hline 1 & $\begin{array}{l}\text { Kajermo } \\
\text { et al. } \\
(1998)\end{array}$ & $\begin{array}{l}\text { To describe the perception of } \\
\text { barriers to and facilitators of } \\
\text { research utilization in a group } \\
\text { of nurse clinicians }\end{array}$ & - & Sweden & 237 & $\begin{array}{l}\text { A survey } \\
\text { study }\end{array}$ & $\begin{array}{c}\text { The major barriers to RU were } \\
\text { insufficient time, unavailability } \\
\text { of research reports and inadequate } \\
\text { facilities for implementation of } \\
\text { new ideas. }\end{array}$ \\
\hline 2 & $\begin{array}{c}\text { Tsai } \\
(2000)\end{array}$ & $\begin{array}{l}\text { To improve understanding of } \\
\text { nurses’ participation in research } \\
\text { activities and their utilization } \\
\text { of research for practice in } \\
\text { one developing country }\end{array}$ & - & China & 382 & $\begin{array}{l}\text { A survey } \\
\text { design }\end{array}$ & $\begin{array}{l}\text { The main barriers to RU were lack } \\
\text { of time, lack of staff, and nurses } \\
\text { working in infection control and } \\
\text { quality improvement have more } \\
\text { tendencies to use research than } \\
\text { critical care nurses. }\end{array}$ \\
\hline 3 & $\begin{array}{l}\text { Parahoo } \\
\text { (2000) }\end{array}$ & $\begin{array}{c}\text { To identify nurses perception } \\
\text { of barriers to and facilitators } \\
\text { of research utilization }\end{array}$ & - & $\begin{array}{l}\text { Northern } \\
\text { Ireland }\end{array}$ & 2600 & $\begin{array}{l}\text { A survey } \\
\text { design }\end{array}$ & $\begin{array}{l}\text { The two major barriers identified } \\
\text { were the nurses do not feel they have } \\
\text { enough authority to change patient } \\
\text { procedures and statistical analysis } \\
\text { is not understandable. }\end{array}$ \\
\hline 4 & $\begin{array}{l}\text { Oranta, } \\
\text { Routasalo, } \\
\text { \& Hupli } \\
\text { (2002) }\end{array}$ & $\begin{array}{c}\text { To identify and describe barriers } \\
\text { to and facilitators of research } \\
\text { utilization from the point of } \\
\text { view of Finnish Registered } \\
\text { Nurses. }\end{array}$ & - & $\begin{array}{l}\text { Turku, } \\
\text { Finland }\end{array}$ & 253 & $\begin{array}{l}\text { Descriptive } \\
\text { study }\end{array}$ & $\begin{array}{l}\text { The barriers are: most research is } \\
\text { published in a foreign language; the } \\
\text { physicians will not co-operate with } \\
\text { implementation; and that statistical } \\
\text { analyses are difficult to understand. }\end{array}$ \\
\hline 5 & $\begin{array}{l}\text { Adamsen } \\
\text { et al. } \\
(2003)\end{array}$ & $\begin{array}{l}\text { To identify the most significant } \\
\text { barriers faced by agroup of } \\
\text { Danish clinical nurses in their } \\
\text { use of research }\end{array}$ & - & Danish & 79 & $\begin{array}{l}\text { An exploratory } \\
\text { and descriptive } \\
\text { design }\end{array}$ & $\begin{array}{l}\text { A major barrier to RU was the vast } \\
\text { amount of research results, and then } \\
\text { nurses feel incapable of evaluating } \\
\text { the quality of research findings as } \\
\text { a result of their knowledge deficit } \\
\text { in research. }\end{array}$ \\
\hline 6 & $\begin{array}{l}\text { McCleary } \\
\text { \& Brown } \\
(2003)\end{array}$ & $\begin{array}{c}\text { To investigate barriers to research } \\
\text { utilization and relationships } \\
\text { between those barriers and } \\
\text { participation inresearch, } \\
\text { self-reported research } \\
\text { utilization and education } \\
\text { among pediatric nurses. }\end{array}$ & 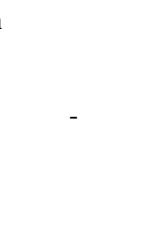 & Canada & 176 & $\begin{array}{l}\text { A survey } \\
\text { study }\end{array}$ & $\begin{array}{l}\text { Lack of time to read research, } \\
\text { administrators not allowing } \\
\text { implementation, characteristics } \\
\text { of the communication and of the } \\
\text { setting, and characteristics of the } \\
\text { nurse ranked as barriers to } \\
\text { research utilization. }\end{array}$ \\
\hline 7 & $\begin{array}{l}\text { Hutchinson } \\
\text { and } \\
\text { Johnston } \\
\text { (2004) }\end{array}$ & $\begin{array}{l}\text { To gain an understanding of } \\
\text { perceived influences on nurses' } \\
\text { utilization of research, and } \\
\text { explore what differences or } \\
\text { commonalities exist between } \\
\text { the findings of this research and } \\
\text { those of studies that have been } \\
\text { conducted in various countries } \\
\text { during the past } 10 \text { years. }\end{array}$ & - & Australia & 761 & $\begin{array}{l}\text { A survey } \\
\text { design }\end{array}$ & $\begin{array}{l}\text { Greatest barriers to research } \\
\text { utilization included time } \\
\text { constraints, lack of awareness } \\
\text { of available research literature, } \\
\text { insufficient authority to change } \\
\text { practice, inadequate skills in } \\
\text { critical appraisal and lack of } \\
\text { support for implementation } \\
\text { of research findings. }\end{array}$ \\
\hline 8 & $\begin{array}{l}\text { Glacken } \\
\text { \& Chaney } \\
\text { (2004) }\end{array}$ & $\begin{array}{l}\text { To ascertain what Registered } \\
\text { Nurses practising in the Republic } \\
\text { of Ireland perceive as barriers to } \\
\text { the implementation of research } \\
\text { findings in the practice setting } \\
\text { and to explore what they } \\
\text { perceive would facilitate them } \\
\text { in using research findings } \\
\text { in their daily practice. }\end{array}$ & -2 & Ireland & 169 & $\begin{array}{l}\text { Cross-sectional } \\
\text { survey }\end{array}$ & $\begin{array}{c}\text { The top barrier was insufficient } \\
\text { authority to instigate change in } \\
\text { the practice setting. }\end{array}$ \\
\hline
\end{tabular}




\section{Continued}

9 Brenner To provide a better understanding

(2005) j of barriers to, and facilitators of, research utilisation

To identify factors influencing the use of research-based practices among staff nurses Squires in the Canadian province of

10 et al. Newfoundland and Labrador (2007) with the specific aim of understanding the role of Policies and procedures in promoting research utilization.

To describe RNs' perceptions of barriers to and facilitators Bostrom of research utilization and to examine the validity of the BARRIERS scale in relation to research use.

Identification of barriers to and facilitators of research

12 Mehrdad et al. (2008)

utilization in nursing practice from the perspective of Iranian nurses

13 Rejeh et al. (2008)

\section{Kajermo et al. (2008)} To identify predictors of nurses
self-reported barriers to using research findings in clinical practice.

To determine Iranian nurses' perceptions of the barriers and facilitators influencing their management of post-operative pain.

\section{Rogers's}

diffusion of Canada

innovations

Ireland

200

Sweden

Iran

410

To describe research activities, to identify barriers to research utilization for practice and to

15 Oh (2008)

Sweden
Korea research barriers aled to critical care nurses.

To examine barriers to and

16 Chau et al (2008)

\section{facilitators of research} utilization.
Hong

Kong,

China
A predominantly

non-experimental

descriptive

design

A cross-sectional survey study
A descriptive design

\section{Qualitative} design with semi-structured serial interviews and analysed using the conten analysis method

Three self-administrated questionnaires were mailed to

the nurses

The most frequently cited barrier was lack of time to implement new ideas. All eight characteristics of the organization feature in the ten highest barriers

The most barriers to RU were lack of time, awareness of the evidence, experience in nursing, physician order, nursing beliefs, patient preferences, and the availability of resources and cost.

The characteristics of the organization such as lack of adequate resources, lack of time to read and implement new ideas, and lack of support from other staff members were the most identified barriers to RU. Also nurses perceived English language as the most barrier to RU.

The three greatest barriers to RU were no enough time to read research studies, inadequate facilities to implement new ideas, and lack of authority to change procedures

The barriers to manage pain after surgery were powerlessness of nurses and depend once on physicians' orders, policies and rules of organization that do not prioritize pain management, physicians' leading, time constraints, limited communication, interruptions of activities related to pain, and insufficient time to interact with patients.

Lack of support from head nurses, unclear and unrealistic purposes for work place, lack of highly educated personnel, and the inclusion of old nurses who did not receive research courses during their education are barriers facing nurses in their practice settings.

Not having clear guidelines for Descriptive
design clinical implications and lack of time to implement new ideas were the greatest barriers.

Inadequate facilities, lack of authority

A cross-sectional, to change practice, lack of time, and correlational lack of cooperation from physicians, exploratory all of these items related to research design organizational characteristics were ranked as the greatest barriers. 


\section{Continued}

To identify practicing nurses' view of aspects which they Salsali and perceived constrain them from research utilization that summarizes and uses research findings to address a nursing practice problem.

(2009)
Iran

15

To assess the levels of perceived barriers to and facilitators of research utilization in practice

Chien

et al.

(2013)

inter-relationships between

these barriers and facilitators and their socio-demographic characteristics

Wang

19 et al.

(2013)

Tawfik

20 et al.

(2014)

and facilitates of research

To describe the perception of barriers to and facilitators of research utilization by registered nurses in Sichuan province, China, and to explore the factors influencing the perceptions of the barriers to and facilitators of research utilization.

utilization in nursing practice from the perspective of nurses in Suez Canal University Hospital.

Investigate the perceived Buhaid barriers to research utilization

in Bahrain and compared the barriers to those of other countries.

To evaluate the perceived research utilization barriers

among nurses in a

Chinomso community hospital in

22 \& Foluso

Nigeria and to assess the

(2014) relationship between their perception and selected socio-demographic variables.

A qualitative approach, the semi-structured interviews

A cross-sectional, descriptive correlational study

A cross sectional survey design

A cross sectional design

Egypt

Bahrain

A cross-sectional exploratory research design

Nigeria

62

A descriptive study
The six themes of the study were: degree of support nurses need to be research users, extent of nurses'

knowledge and skills in RU, levels of educational training involving research, research mindedness, administration and executive challenges in clinical setting and theory-practice gap. All of these themes were considered as barriers to RU

The six top ranked barriers from the subscale "Organizational Characteristics” were mainly related to limitations of resources, facilities and nursing manpower in the nurses' workplaces or organizations, for example, "There is insufficient time on the job to implement new ideas" (i.e., the top barrier) The nurse does not see the value of research for practice nurses' (i.e., the second one) and "The nurse is unaware of the research" (i.e., the fifth one).

The lack of authority was ranked as the top greatest barrier, followed by the lack of time and language barrier

The greatest barriers to research utilization were the inadequacy of facilities for implementation, the delay in publishing research reports, the unclear implications of research utilization for practice, the physicians' non-cooperation and the insufficient time to read researches.

The top three ranked barriers were lack of authority to change practice, inadequate facilities and time constraints. Of the top 10 ranked barriers, six items were related to the subscale organization

The major barriers identified were issues with administration, lack of cooperation from physicians and

lack of time to read research among nurses, insufficient time to implement changes and unwillingness to change or try new things. 


\section{Continued}

$\mathrm{Al}$

23 Ghabeesh,

S. et al.

(2014)
To explore the predictors

that facilitate and/or

limit the utilization

of research findings
Jordan
The top five barriers were related to organizational characteristics as follows: routines in providing nursing care dominate, lack of consistency between education and practice in nursing discipline, lack of organizational and administrative motivation for its employee to do research, the nurse is too busy providing patient care and has no time to read research reports or studies, and the shortage of staff nurses hinders the implementation of new evidences.

Reviewed studies in the field of suggested facilitators to research utilization

\begin{tabular}{|c|c|c|c|c|c|c|c|}
\hline \multicolumn{8}{|c|}{ Reviewed studies in the field of suggested facilitators to research utilization } \\
\hline 1 & $\begin{array}{c}\text { Kajermo } \\
\text { et al. } \\
\text { (1998) }\end{array}$ & $\begin{array}{l}\text { To describe the perception of } \\
\text { barriers to and facilitators of } \\
\text { research utilization in a group } \\
\text { of nurse clinicians }\end{array}$ & - & Sweden & 237 & $\begin{array}{l}\text { A survey } \\
\text { study }\end{array}$ & $\begin{array}{l}\text { Nurses mentioned } 290 \text { suggestions } \\
\text { to facilitate RU. Those suggestions } \\
\text { were categorized into five groups; } \\
\text { knowledge, communication, } \\
\text { resources, support and attitudes, } \\
\text { and research. }\end{array}$ \\
\hline 2 & $\begin{array}{l}\text { Tsai } \\
(2000)\end{array}$ & $\begin{array}{l}\text { To improve understanding of } \\
\text { nurses’ participation in research } \\
\text { activities and their utilization of } \\
\text { research for practice in one } \\
\text { developing country, }\end{array}$ & - & China & 382 & $\begin{array}{c}\text { A survey } \\
\text { design }\end{array}$ & $\begin{array}{l}\text { RU can be facilitated through the } \\
\text { creation of a "research corner" in each } \\
\text { clinical unit for poster display and } \\
\text { discussion and presentation of } \\
\text { research findings in an open debate. }\end{array}$ \\
\hline 3 & $\begin{array}{c}\text { Parahoo } \\
\text { (2000) }\end{array}$ & $\begin{array}{l}\text { To identify nurses perception of } \\
\text { barriers to and facilitators of } \\
\text { research utilization }\end{array}$ & - & $\begin{array}{l}\text { Northern } \\
\text { Ireland }\end{array}$ & 2600 & $\begin{array}{l}\text { A survey } \\
\text { design }\end{array}$ & $\begin{array}{l}\text { The respondents reported } 37 \\
\text { facilitators. The researcher carried } \\
\text { out content analysis and the common } \\
\text { themes emerged were: time, } \\
\text { manager's support, fundinglresources, } \\
\text { support from colleagues, education } \\
\text { and training, research presentation, } \\
\text { and motivation. }\end{array}$ \\
\hline 4 & $\begin{array}{l}\text { Oranta, } \\
\text { Routasalo, } \\
\text { \& Hupli } \\
\text { (2002) }\end{array}$ & $\begin{array}{l}\text { To identify and describe barriers } \\
\text { to and facilitators of research } \\
\text { utilization from the point of } \\
\text { view of Finnish Registered } \\
\text { Nurses. }\end{array}$ & - & $\begin{array}{l}\text { Turku, } \\
\text { Finland }\end{array}$ & 253 & $\begin{array}{l}\text { Descriptive } \\
\text { study }\end{array}$ & $\begin{array}{l}\text { The facilitators were: nurses' positive } \\
\text { attitudes and abilities, the support } \\
\text { and activity of a ward sister as well } \\
\text { as encouragement, a favorable } \\
\text { attitude and collaboration on the } \\
\text { part of all staff members. }\end{array}$ \\
\hline 5 & $\begin{array}{l}\text { Hutchinson } \\
\text { and Johnston } \\
\text { (2004) }\end{array}$ & $\begin{array}{l}\text { To gain an understanding of } \\
\text { perceived influences on nurses' } \\
\text { utilization of research, and } \\
\text { explore what differences or } \\
\text { commonalities exist between } \\
\text { the findings of this research and } \\
\text { those of studies that have been } \\
\text { conducted in various countries } \\
\text { during the past } 10 \text { years. }\end{array}$ & - & Australia & 761 & $\begin{array}{c}\text { A survey } \\
\text { design }\end{array}$ & $\begin{array}{l}\text { Availability of more time to review } \\
\text { and implement research findings, } \\
\text { availability of more relevant research } \\
\text { and colleague support. }\end{array}$ \\
\hline 6 & $\begin{array}{l}\text { Glacken } \\
\text { \& Chaney } \\
\text { (2004) }\end{array}$ & $\begin{array}{l}\text { To ascertain what Registered } \\
\text { Nurses practising in the Republic } \\
\text { of Ireland perceive as barriers to } \\
\text { the implementation of research } \\
\text { findings in the practice setting } \\
\text { and to explore what they } \\
\text { perceive would facilitate them } \\
\text { in using research findings in } \\
\text { their daily practice. }\end{array}$ & - & Ireland & 169 & $\begin{array}{l}\text { Cross-sectional } \\
\text { survey }\end{array}$ & $\begin{array}{l}\text { The perceived key facilitators to } \\
\text { implementing research findings } \\
\text { included protected time for retrieval } \\
\text { and evaluation of research findings, } \\
\text { instrumental support from } \\
\text { management, informed supportive } \\
\text { personnel in the practice settings and } \\
\text { accessible educational opportunities } \\
\text { to augment critical reading skills. }\end{array}$ \\
\hline
\end{tabular}




\section{Continued}

Brenner To provide a better understanding

j of barriers to, and facilitators of, research utilisation
Ireland

A predominantly non-experimental descriptive design
Identification of barriers to and facilitators of research

Mehrdad et al. (2008) from the perspective of Iranian nurses

To examine barriers to and facilitators of research utilization.

To determine Iranian nurses' perceptions of the barriers and facilitators influencing their management of post-operative pain.

To identify the presence or absence of provider and organizational variables

Leasure

(2008) associated with the use of evidence based best practices among nurses.

To describe RNs' perceptions of barriers to and facilitators Bostrom of research utilization and 12 et al. (2008) to examine the validity of the BARRIERS scale in relation to research use.

To assess the levels of perceived barriers to and facilitators of Chien research utilization in practice among Chinese nurses and

(2013) inter-relationships between these barriers and facilitators and their socio-demographic characteristics

To describe the perception of barriers to and facilitators of research utilization by registered nurses in Sichuan province, China, and to explore the factors

Iran

\section{A descriptive design}

Hong
Kong,
China 5000 correlational exploratory

\section{Oklahoma A convenience \\ City, sample of \\ 11 nurse executives}

A cross-sectional, research design

Qualitative design with semi-structured serial interviews and analysed using the content analysis method
Descriptive correlational study design.
Greater support from nursing management is a priority, with respondents outlining a need for

“... active support from senior nurse managers for nurses at the 'front line' of delivery service”. In relation to resources, protected time, access to adequate library facilities and increased financial support were identified as facilitators of research utilisation.
Facilitators were categorized into two main groups of human resources and individual/organizational factors.

Managerial support, colleague support, and increasing nursing knowledge about research were the three greatest organizational facilitators for RU

The facilitators to pain management post-operatively were the nurse-patient relationship which provided better view of patients' pain, nurses' responsibility, physician as a colleague, and nurses' knowledge and skills.

The facilitators to RU comprise reading journals that publish original research, establishing a journal club, the availability of a nursing research committee and easy access to the internet.

Support from unit managers is

A cross-sectional the greatest facilitator to RU.

the barriers to and facilitators of research utilization.

China $\quad 743 \quad \begin{gathered}\text { descriptive } \\ \text { correlational } \\ \text { study }\end{gathered}$

China

590
The three top perceived facilitators included: "Advanced education to increase your research knowledge base", "Improving availability and accessibility of research reports" and "Enhancing managerial support and encouragement of research implementation”

The top three greatest facilitators were enhancing managerial support A cross sectional (36.9\%), advancing education to survey design increase knowledge base (21.1\%), and increasing time for reviewing and implementing 


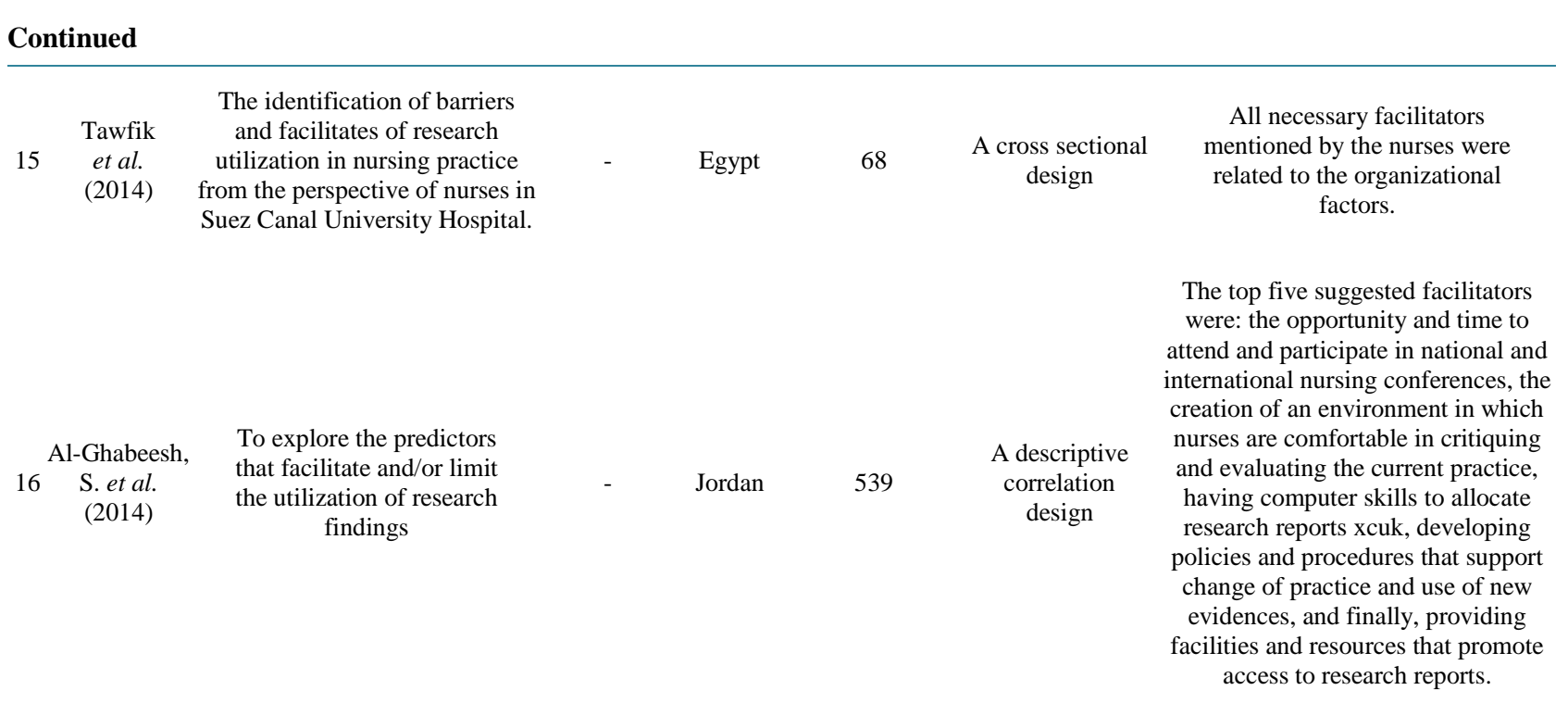

Reviewed studies in the field of Strategies used to increase research utilization

\begin{tabular}{|c|c|c|c|c|c|c|c|}
\hline \multicolumn{8}{|c|}{ Reviewed studies in the field of Strategies used to increase research utilization } \\
\hline 1 & $\begin{array}{c}\text { Fink, } \\
\text { Thompson, } \\
\text { and Bonnes } \\
\text { (2005) }\end{array}$ & $\begin{array}{l}\text { To identify inpatient nurses’ } \\
\text { personal and professional } \\
\text { characteristics, perceptions } \\
\text { of organizational culture, } \\
\text { and the effectiveness of } \\
\text { organizational strategies. }\end{array}$ & $\begin{array}{c}\text { Rogers' } \\
\text { Diffusion of } \\
\text { Innovations }\end{array}$ & Denver & $\begin{array}{l}\text { At baseline } \\
\text { ( } \mathrm{n}=215) ; \\
\text { post intervention } \\
\text { implementation } \\
\text { ( } \mathrm{n}=239) .\end{array}$ & $\begin{array}{l}\text { A descriptive, } \\
\text { cross-sectional, } \\
\text { presurvey and } \\
\text { postsurvey } \\
\text { design }\end{array}$ & $\begin{array}{l}\text { There was improvement in } \\
\text { nurses' perception of barriers } \\
\text { and organizational culture } \\
\text { post implementation of the } \\
\text { multifaceted intervention. } \\
\text { Journal club participation was } \\
\text { one of the key strategies that } \\
\text { facilitated research utilization. }\end{array}$ \\
\hline 2 & $\begin{array}{c}\text { Long } \\
\text { (2010) }\end{array}$ & $\begin{array}{l}\text { Can clinical practice guidelines } \\
\text { developed by the RNAO in } \\
\text { Canada be used to improve } \\
\text { identification and management } \\
\text { of women receiving postpartum } \\
\text { care in a private obstetrics } \\
\text { practice in the United States? }\end{array}$ & $\begin{array}{c}\text { Stetler } \\
\text { Model of } \\
\text { Research } \\
\text { Utilization }\end{array}$ & America & $\begin{array}{l}\text { One of } 170 \\
\text { postpartum } \\
\text { patients prior } \\
\text { to the initiation } \\
\text { of the RNAO } \\
\text { Guidelines and } \\
\text { one of } 168 \\
\text { patients post } \\
\text { guidelines } \\
\text { administration }\end{array}$ & $\begin{array}{c}\text { Two } \\
\text { retrospective } \\
\text { chart reviews } \\
\text { over a six-week } \\
\text { period }\end{array}$ & $\begin{array}{l}\text { The greater facilitator to this } \\
\text { success reported was the } \\
\text { leadership style of the } \\
\text { organization (autonomy), } \\
\text { which encouraged } \\
\text { role-modeling } \\
\text { and increased RU. }\end{array}$ \\
\hline
\end{tabular}

\section{Results}

\subsection{Characteristics of the Reviewed Studies}

$88 \%$ (23) of the studies used descriptive cross sectional survey design, two studies used qualitative design and only one study used retrospective design. The sample size ranged from 11 to 2600 , the lowest sample size included in qualitative studies. The samples in all studies were only nurses working in various specialties and settings. Only $12 \%$ of the studies conducted in Arab countries.

\subsection{Barriers to Research Utilization}

Nurses in clinical areas face many barriers to implement research findings into their practice. These barriers are varying between different countries and from clinical area to another, but it's clear that there is no changes in the barriers to RU between the years 1998 and 2014 and that most barriers are related to the characteristics of the organization, few studies tried to challenge these barriers.

The results of the reviewed studies revealed that all the twenty three studies related to barriers to RU emphasized on organizational factors that it is the main factor inhibit RU. Lack of time is the mostmentioned barrier to RU and it is mentioned in more than 73.84\% (17) of the studies [5] [8]-[17] [19]-[24]. Followed by inadequate 
facilities and resources also mentioned by 34.72\% (8) of studies [5] [9] [14]-[16] [19] [21] [22]. Then, no enough authority to change practice mentioned by 30.38\% (7) of reviewed studies [5] [12] [16] [20] [22] [25] [26]. The fourth most mentioned barrier is lack of support from administrators which mentioned by $26 \%$ (6) of reviewed studies [7] [11] [12] [15] [18] [19]. While other barriers such as unavailability of research reports, lack of staff, difficulties in understanding statistical analysis, using foreign language, routines in providing nursing care dominate, lack of cooperation from physicians, vast amount of research, low skills of nurses to understand research reports, and others [23] [27] [28].

\subsection{Facilitators to Research Utilization}

Several studies have investigated the suggested facilitators to RU. Bostromand his colleagues stated that support from unit managers is the greatest facilitator to RU [15]. On the other hand, in Kajermo et al.'s study, nurses mentioned 290 suggestions to facilitate RU [9]. Those suggestions were categorized into five groups; knowledge, communication, resources, support and attitudes, and research. Improving the scientific knowledge of nurses was the most frequently mentioned facilitators to RU beside the availability of "user friendly" reported research. Education in scientific methods, developing skills in searching for appropriate literature, and guidance from knowledgeable colleagues were the most suggested facilitators related to the knowledge. Translation of the articles into understandable language, presenting the results in an understandable way, information about the researches that carried out in their country and the availability of specific scientific nursing journals were the most suggested facilitators related to communication. Time, money and staffing were the category of resources that the nurses emphasized as facilitators to RU related to resources. Respect from other professionals, and interest, courage, and willingness to carry out changes, and encouragement from managers were the most suggested facilitators related to support and attitudes. More realistic and relevant research closer to reality was the most suggested facilitators related to research. Other studies emphasized the key role that the organization can play to promote RU [8] [9].

Tsai found that RU can be facilitated through the creation of a "research corner" in each clinical unit for poster display and discussion and presentation of research findings in an open debate [10]. On the other hand, Chau, et al. found that managerial support, colleague support, and increasing nursing knowledge about research were the three greatest organizational facilitators for RU [16].

Parahoo asked an open ended question to identify the facilitators to RU as perceived by registered nurses [25]. The respondents reported 37 facilitators. The researcher carried out content analysis and the common themes emerged were: time, manager's support, funding search presentation, and motivation. Under the theme "education and training" the opportunities for study, study days and continuing education were identified as facilitators for RU.

The greatest facilitators to RU as identified in Hutchinson and Johnston included availability of more time to review and implement research findings, availability of more relevant research and colleague support [12]. On the other hand, Leasure et al. in their study identified that the facilitators to RU comprise reading journals that publish original research, establishing a journal club, the availability of a nursing research committee and easy access to the internet [29]. The establishment of small groups three to four staff members with evidence of critical appraisal abilities to review one procedure at a time and this review should be recognized in annual evaluation was also suggested as a facilitator to RU.

In Long dissertation, the evidence-based practice guidelines developed by the Registered Nurses Association of Ontario (RNAO) in Canada was used to improve the identification and management of women receiving postpartum care in a private obstetrical practice in the United States [30]. These evidence-based practice guidelines were operationalized by the use of the Edinburgh Postnatal Depression Scale (EPDS). Upon the implementation of the RNAO Guidelines, 96\% of postpartum patients were screened by the EPDS and the number of patients at risk for postpartum depression (PPD) also increased from $4.7 \%$ to $11 \%$. The greater facilitator to this success reported was the leadership style of the organization (autonomy), which encouraged role-modeling and increased RU. Additionally, Fink, Thompson, and Bonnesin their study found that post implementation of the multidimensional intervention [31]. Journal club participation was one of the key strategies that facilitated RU.

\section{Discussion}

This review demonstrated that nurses faced many barriers to RU. Some of them were identified by using specific 
instruments and others by conducting qualitative studies. The barriers to RU were the same in all units in hospitals and around the world and didn't change since 1998 until now. Thirty three barriers were identified in the reviewed literature; most of these barriers were related to characteristics of organization. The most identified barriers are lack of time, inadequate facilities and resources, lack of authority to implement new ideas, and lack of managerial support.

On the other hand, there are several facilitators to RU that the literature revealed. The most frequently cited facilitators were the availability of enough time to read and implement research findings, the availability of managerial support and resources. The most important strategy suggested encouraging RU is the identification of the barriers to RU and the organization effort to overcome those barriers to achieve their goals.

The majority of these studies used Barriers scale which is not a standardized tool [32]. Thus, this review will add new items to the Barriers Scale based on literature to explore further barriers and facilitators to RU.

\section{Conclusion}

Nursing administrators must condense their efforts to resolve these big challenges to increase the quality of life of hospitalized patients. The application of suggested facilitators into real situation must be encouraged.

\section{References}

[1] Santesso, N. and Tugwell, P. (2006) Knowledge Translation in Developing Countries. The Journal of Continuing Education in the Health Professions, 26, 87-96. http://dx.doi.org/10.1002/chp.55

[2] Khalaf, I. (2010) Expanding Horizons of Nursing Education and Practice in Jordan through Research Utilization. Unpublished Study, Presented at Faculty of Nursing First Scientific Nursing Conference, Zarqa Private University, Zarqa.

[3] Veeramah, V. (2004) Utilization of Research Findings by Graduate Nurses and Midwives. Journal of Advanced Nursing, 47, 183-191. http://dx.doi.org/10.1111/j.1365-2648.2004.03077.x

[4] Kuuppelomaki, M. and Tuomi, J. (2005) Finnish Nurses’ Attitudes towards Nursing Research and Related Factors. International Journal of Nursing Studies, 42, 187-196. http://dx.doi.org/10.1016/j.ijnurstu.2004.06.001

[5] Mehrdad, N., Salsali, M. and Kazemnejad, A. (2008) The Spectrum of Barriers to and Facilitators of Research Utilization in Iranian Nursing. Journal of Clinical Nursing, 17, 2194-2202. http://dx.doi.org/10.1111/j.1365-2702.2007.02040.x

[6] Ofi, B., Sowunmi, L., Edet, D. and Anarado, N. (2008) Professional Nurses' Opinion on Research and Research Utilization for Promoting Quality Nursing Care in Selected Teaching Hospitals in Nigeria. International Journal of Nursing Practice, 14, 243-255. http://dx.doi.org/10.1111/j.1440-172X.2008.00684.X

[7] Kajermo, K.N., Unden, M., Gardulf, A., Eriksson, L.E., Orton, M., Arnetz, B.B. and Nordstrom, G. (2008) Predictors of Nurses' Perceptions of Barriers to Research Utilization. Journal of Nursing Management, 16, 305-314. http://dx.doi.org/10.1111/j.1365-2834.2007.00770.x

[8] Oh, E.G. (2008) Research Activities and Perceptions of Barriers to Research Utilization among Critical Care Nurses in Korea. Intensive and Critical Care Nursing, 24, 314-322. http://dx.doi.org/10.1016/j.iccn.2007.12.001

[9] Kajermo, K.N., Nordstrom, G., Krusebrant, A. and Bjorvell, H. (1998) Barriers to and Facilitators of Research Utilization, as Perceived by a Group of Registered Nurses in Sweden. Journal of Advanced Nursing, 27, 798-807. http://dx.doi.org/10.1046/j.1365-2648.1998.00614.x

[10] Tsai, S. (2000) Nurses' Participation and Utilization of Research in the Republic of China. International Journal of Nursing Studies, 37, 435-444. http://dx.doi.org/10.1016/S0020-7489(00)00023-7

[11] McCleary, L. and Brown, G.T. (2003) Barriers to Pediatric Nurses’ Research Utilization. Journal of Advanced Nursing, 42, 364-372. http://dx.doi.org/10.1046/j.1365-2648.2003.02628.x

[12] Hutchinson, A.M. and Johnston, F. (2004) Bridging the Divide: A Survey of Nurses’ Opinions Regarding Barriers to and Facilitators of Research Utilization in the Practice Setting. Journal of Clinical Nursing, 13, 304-315. http://dx.doi.org/10.1046/j.1365-2702.2003.00865.x

[13] Brenner, M. (2005) Children's Nursing in Ireland Barriers to, and Facilitators of, Research Utilization. Paediatric Nursing, 17, 40-45. http://dx.doi.org/10.7748/paed2005.05.17.4.40.c990

[14] Squires, J.E., Moralejo, D. and LeFort, S.M. (2007) Exploring the Role of Organizational Policies and Procedures in Promoting Research Utilization in Registered Nurses. Implementation Science, 2, 1-11.

[15] Bostrom, A.M., Kajermo, K.N., Nordstrom, G. and Wallin, L. (2008) Barriers to Research Utilization and Research Use among Registered Nurses Working in the Care of Older People: Does the BARRIERS Scale Discriminate between Research Users and Non-Research Users on Perceptions of Barriers? Implementation Science, 3, 24. 
[16] Chau, J.P., Lopez, V. and Thompson, D.R. (2008) A Survey of Hong Kong Nurses’ Perceptions of Barriers to and Facilitators of Research Utilization. Research in Nursing \& Health, 31, 640-649. http://dx.doi.org/10.1002/nur.20289

[17] Rejeh, N., Ahmadi, F., Mohammadi, E., Anoosheh, M. and Kazemnejad, A. (2008) Barriers to, and Facilitators of Post-Operative Pain Management in Iranian Nursing: A Qualitative Research Study. International Nursing Review, 55, 468-475. http://dx.doi.org/10.1111/j.1466-7657.2008.00659.x

[18] Salsali, M. and Mehrdad, N. (2009) Iranian Nurses’ Constraint for Research Utilization. BMC Nursing, 8, 1-11.

[19] Chien, W., Bai, Q., Wong, W., Wang, H. and Lu, X. (2013) Nurses’ Perceived Barriers to and Facilitators of Research Utilization in Mainland China: A Cross-Sectional Survey. The Open Nursing Journal, 7, 96-106. http://dx.doi.org/10.2174/1874434601307010096

[20] Wang, L.P., Jiang, X., Wang, L., Wang, G. and Bai, Y. (2013) Barriers to and Facilitators of Research Utilization: A Survey of Registered Nurses in China. PLOS ONE, 8, e81908. http://dx.doi.org/10.1371/journal.pone.0081908

[21] Tawfik, M.Y., Mohamed, N.I. and Moussa, M.M. (2014) Barriers and Facilitates of Research Utilization as Perceived by Nurses of Suez Canal University Hospital-Ismailia-Egypt. Journal of American Science, 10, 89-96.

[22] Buhaid, N., Lau, R. and O’Connor, M. (2014) A Survey of Nurses’ Perceived Barriers to Research Utilization in Bahrain in Comparison to Other Countries. Middle East Journal of Nursing, 8, 3-9. http://dx.doi.org/10.5742/MEN.2014.92475

[23] Chinomso, N. and Foluso, O. (2014) Perceived Research Utilization Barriers among Nurses in a Rural Hospital in Nigeria. International Journal of Advancements in Research \& Technology, 3, 184-191.

[24] Al-Ghabeesh, S., Abu-Moghli, F. and Suleiman, K. (2014) Predictors of Research Utilization among Jordanian Registered Nurses: A Descriptive Correlational Study. International Journal of Medicine and Medical Sciences, 47, 1530 1538.

[25] Parahoo, K. (2000) Barriers to, and Facilitators of, Research Utilization among Nurses in Northern Ireland. Journal of Advanced Nursing, 31, 89-98. http://dx.doi.org/10.1046/j.1365-2648.2000.01256.x

[26] Glacken, M. and Chaney, D. (2004) Perceived Barriers and Facilitators to Implementing Research Findings in the Irish Practice Setting. Journal of Clinical Nursing, 13, 731-740. http://dx.doi.org/10.1111/j.1365-2702.2004.00941.x

[27] Oranta, O., Routasalo, P. and Hupli, M. (2002) Barriers to and Facilitators of Research Utilization among Finnish Registered Nurses. Journal of Clinical Nursing, 11, 205-213. http://dx.doi.org/10.1046/j.1365-2702.2002.00587.x

[28] Adamsen, L., Larsen, K., Bjerregaard, L. and Madsen, J.K. (2003) Danish Research-Active Clinical Nurses Overcome Barriers in Research Utilization. Scandinavian Journal of Caring Science, 17, 57-65. http://dx.doi.org/10.1046/j.1471-6712.2003.00124.x

[29] Leasure, A.R., Stirlen, J. and Thompson, C. (2008) Barriers and Facilitators to the Use of Evidence-Based Best Practices. Dimensions of Critical Care Nursing, 27, 74-82. http://dx.doi.org/10.1097/01.DCC.0000311600.25216.c5

[30] Long, V.E. (2010) Adaptation of a Best Practice Model for Recognition and Treatment of Postpartum Depression in a Private Obstetrics Practice: An Evidence-Based Practice Project. Doctoral Dissertation, the Catholic University of America, Washington DC. ProQuest Digital Dissertations, UMI Number: 3403481.

[31] Fink, R., Thompson, C.J. and Bonnes, D. (2005) Overcoming Barriers and Promoting the Use of Research in Practice. Journal of Nursing Administration, 35, 121-129. http://dx.doi.org/10.1097/00005110-200503000-00005

[32] Kajermo, K.N., Bostrom, A., Thompson, D.S., Hutchinson, A.M., Estabrooks, C.A. and Wallin, L. (2010) The BARRIERS Scale-The Barriers to Research Utilization Scale: A Systematic Review. Implementation Science, 5, 32. http://dx.doi.org/10.1186/1748-5908-5-32 
Scientific Research Publishing (SCIRP) is one of the largest Open Access journal publishers. It is currently publishing more than 200 open access, online, peer-reviewed journals covering a wide range of academic disciplines. SCIRP serves the worldwide academic communities and contributes to the progress and application of science with its publication.

Other selected journals from SCIRP are listed as below. Submit your manuscript to us via either submit@scirp.org or Online Submission Portal.
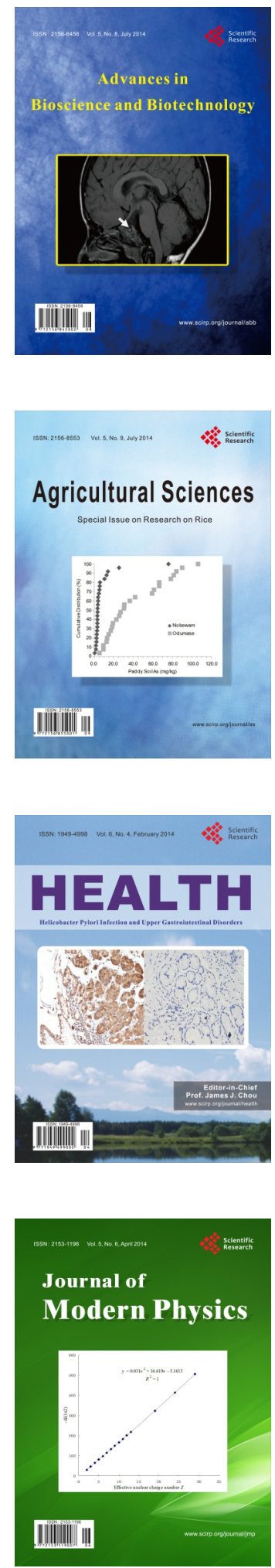
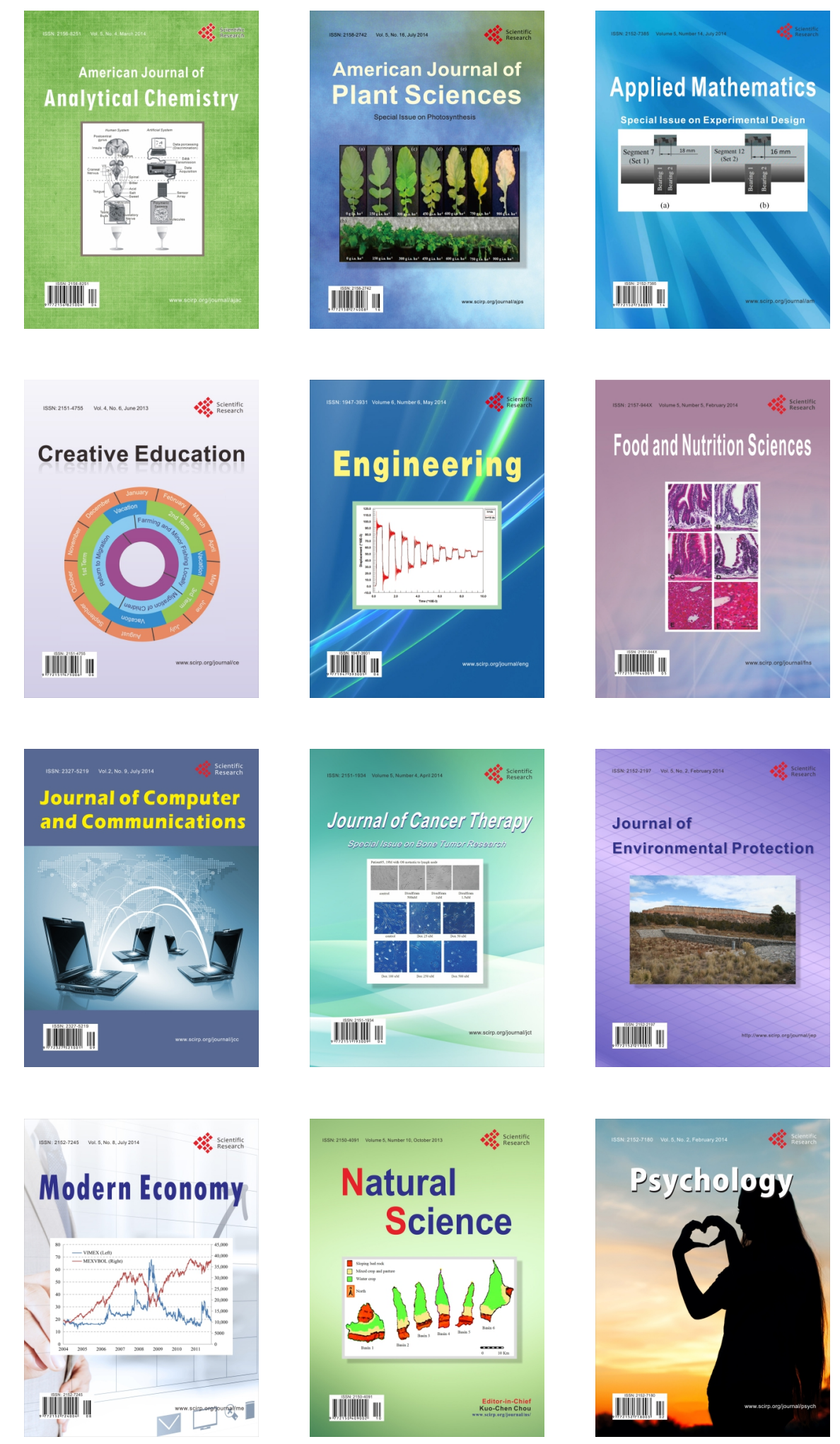